\title{
Association of Decreased Natural and Antibody-Dependent Cellular Cytotoxicity and Production of Natural Killer Cytotoxic Factor and Interferon in Neonates ${ }^{1}$
}

\author{
Madhavan P. N. NaIR, ${ }^{*, 2}$ Stanley A. Schwartz, ${ }^{*, 3}$ \\ and Mangaladevi MENON† \\ Departments of *Pediatrics and Epidemiology and †Obstetrics and Gynecology, \\ University of Michigan, Ann Arbor, Michigan 48109
}

Received February 4, 1985; Accepted March 15, 1985

\begin{abstract}
Cord blood lymphocytes (CBL) were compared with adult peripheral blood lymphocytes (a-PBL) for their: (i) natural killer (NK) and antibody-dependent cellular cytotoxic (ADCC) activities, (ii) target-binding capacity, (iii) ability to induce soluble natural kifler cytotoxic factor (NKCF), (iv) interferon (IFN)-, interleukin 2 (IL-2)-, and lectin-induced augmentation of NK activity, and (v) ability to produce IFN against tumor targets in vitro. CBL depleted of adherent cells and Percoll-separated, NK-enriched subpopulations demonstrated significantly lower NK, ADCC, and target-binding activities compared to a-PBL. CBL produced significantly lower levels of NKCF directed against K562 tumor targets in comparison with a-PBL. Although the NK activity of CBL was not stimulated by cither IFN or IL-2 to the same levels shown by a-PBL, the percentage enhancement of cytotoxicity of CBL by IFN and IL-2 was greater than that of a-PBL. Lectin-induced enhancement of cytotoxicity was significantly greater for CBL in comparison with a-PBL. Further, the ability of CBL lymphocytes to produce IFN- $\gamma$ in vitro against K562 target cells was significantly lower than that of adult PBL. These studies suggest an association between decreased NK, ADCC, and target-binding activities, induction of NKCF and IFN production by $\mathrm{CBL}$, and increased susceptibility of neonates to infection. (c) 1985 Academic Press, Inc.
\end{abstract}

\section{INTRODUCTION}

Neonates are known to have increased susceptibility to disseminated and devastating infections $(1,2)$. Earlier studies showed that the immune system of the newborn is deficient in several aspects of humoral and cellular immunity $(1,3)$. Natural killer $(\mathrm{NK})^{4}$ cells and cells mediating antibody-dependent cellular cytotoxic

${ }^{1}$ This work was aided by grants from the National Institutes of Health (CA35922 and AI-19890), the Children's Leukemia Foundation of Michigan, and the Michigan Diabetes Research and Training Center of the University of Michigan.

${ }^{2}$ To whom all correspondence should be addressed at: Room 1029, School of Public Health I, Department of Pediatrics, University of Michigan, Ann Arbor, Michigan 48109.

${ }^{3}$ Recipient of NIH Research Career Development Award CA-08896.

${ }^{4}$ Abbreviations used: ADCC, antibody-dependent cellular cytotoxicity; a-PBL, adult peripheral blood lymphocytes depleted of adherent cells; CBL, cord blood lymphocytes depleted of adherent cells; NK, natural killer; NKCF, natural killer cytotoxic factor; IFN, interferon; IL-2, interleukin 2; LGL, large granular lymphocytes; FCS, fetal calf serum; LDCC, lectin-dependent cell-mediated cytotoxicity; PHA, phytohemagglutinin; LU, lytic units; Hepes, 4-(2-hydroxyethyl)-1-piperazineethanesulfonic acid. 
(ADCC) activities are important because of their probable role in immune surveillance against cancer and viral infections and in the regulation of various lymphocyte reactions (4-7). Regulatory effects of NK cells on hematopoietic stem cell proliferation have been demonstrated (8). The ability of cord blood lymphocytes (CBL) to mediate NK and ADCC activities has been reported with conflicting findings (914). The present study examines the NK and $A D C C$ activities of CBL in comparison with adult lymphocytes (a-PBL) and attempts to delineate the molecular and cellular basis of the NK defect by examining the target-binding ability and production of natural killer cytotoxic factor (NKCF) and interferon (IFN) in vitro. These studies are consistent with a relationship between the deficiency of NK, ADCC, and targetbinding activities of cord blood lymphocytes and reduced NKCF and IFN production.

\section{MATERIALS AND METHODS}

\section{Preparation of Effector Cells}

Neonatal umbilical cord blood samples were collected in heparinized tubes (20 $\mathrm{U} / \mathrm{ml}$ ) under sterile conditions from healthy term infants at vaginal delivery before the expulsion of the placenta. Heparinized $(20 \mathrm{U} / \mathrm{ml})$ peripheral blood was obtained simultaneously from healthy unrelated adult volunteers of either sex (20 to 40 years of age). Blood samples were processed immediately after collection. Donors or their parents were apprised of the study and consents were obtained consistent with the policies of the University of Michigan and the NIH. Mononuclear cells from both adult and cord blood samples were isolated using a modified method of Boyum (15). Blood was diluted with an equal volume of $\mathrm{Ca}^{2+}$ and $\mathrm{Mg}^{2+}$-free Hanks' balanced salt solution [HBSS (GIBCO, Grand Island, N.Y.)] and centrifuged at $400 \mathrm{~g}$ for $30 \mathrm{~min}$ at $18^{\circ} \mathrm{C}$ over a cushion of Ficoll-Hypaque (Pharmacia Fine Chemicals, Piscataway, N.J.). The mononuclear cell band was harvested, washed three times with HBSS, and resuspended in RPMI 1640 medium containing 25 $\mathrm{m} M$ Hepes buffer supplemented with $10 \%$ heat-inactivated fetal calf serum [FCS (GIBCO)], $80 \mu \mathrm{g} / \mathrm{ml}$ gentamicin (Schering Corp., Kenilworth, N.J.), and $300 \mu \mathrm{g}$ fresh glutamine/ml (complete medium).

\section{Depletion of Adherent Cells}

Mononuclear cells were depleted of adherent cells as described (6). Briefly, total mononuclear cells were suspended in RPMI 1640 with 10\% FCS and passaged through a 7-ml column of Sephadex G-10 beads (Pharmacia) equilibrated in the same medium. After $45 \mathrm{~min}$ of incubation at $37^{\circ} \mathrm{C}$, nonadherent cells were washed through with 1 bed vol of warm $\left(37^{\circ} \mathrm{C}\right)$ medium. The cell recovery was $>70 \%$ of the total input, and monocyte contamination as indicated by nonspecific esterase staining was $<2 \%$.

\section{Percoll Fractionation of Lymphocytes}

The enrichment of NK and ADCC effector cells using a discontinuous gradient of Percoll (Pharmacia) was carried out as described elsewhere (6). To prepare a discontinuous density gradient, Percoll solution was mixed at various concentrations with RPMI 1640 medium and $2-\mathrm{ml}$ aliquots (ranging from 50.0 to $37.5 \%$ in $2.5 \%$ increments) were gently layered into $15 \times 130-\mathrm{mm}$ round-bottom glass test tubes. 
Adherent cell-depleted lymphocytes were layered on top of the gradient and centrifuged at $300 \mathrm{~g}$ for $45 \mathrm{~min}$ at $20^{\circ} \mathrm{C}$. Six fractions, with the uppermost $(37.5 \%)$ designated " $O$ " and the lowermost (50.0\%) designated " $V$ ", were collected from the top with a Pasteur pipet and washed twice in RPMI 1640 medium. Recovery of cells was $\sim 85 \%$ of the input, and viability always exceeded $95 \%$ by trypan blue dye exclusion.

\section{Preparation of Tumor Target Cells}

Mycoplasma-free human erythroleukemia cell line K-562 was used as target for NK cells. For the ADCC assay, we chose as target an antibody-coated human B-cell leukemia line (SB) because of its resistance to $\mathrm{NK}$ activity in a $4-\mathrm{hr}{ }^{51} \mathrm{Cr}$ release assay. Tumor target cells were serially passaged in complete medium and used in cytotoxicity assays no more than $48 \mathrm{hr}$ after the last passage. To $0.8-\mathrm{ml}$ aliquots of complete medium containing $5 \times 10^{6}$ washed tumor cells, $200 \mu \mathrm{Ci}$ of ${ }^{51} \mathrm{Cr}$ as sodium chromate (New England Nuclear, Boston, Mass.) was added. The cells were incubated at $37^{\circ} \mathrm{C}$ for $1 \mathrm{hr}$ in a humidified atmosphere of $5 \% \mathrm{CO}_{2}$ in air, with intermittent shaking. After incubation, the cells were washed three times with complete medium and resuspended to a concentration of $1 \times 10^{5} \mathrm{cells} / \mathrm{ml}$.

\section{Assay for NK Activity}

NK activity was measured in a direct ${ }^{51} \mathrm{Cr}$ release assay as previously described $(6,16,17)$. A fixed number of viable effector cells in complete medium was added to triplicate cultures of ${ }^{51} \mathrm{Cr}$-labeled targets in V-bottom microtitration plates (CoStar, Cambridge, Mass.). After centrifugation at $40 \mathrm{~g}$ for $2 \mathrm{~min}$, they were incubated at $37^{\circ} \mathrm{C}$ in a humidified atmosphere of $5 \% \mathrm{CO}_{2}$ in air for $4 \mathrm{hr}$. At the end of incubation the plates were centrifuged at $400 \mathrm{~g}$ for $10 \mathrm{~min}$ and 100 - $\mu$ l aliquots were removed from each well and transferred to glass tubes and read in a Packard Model 593 gamma counter. Percentage cytotoxicity was calculated as follows:

$$
\% \text { cytotoxicity }=\frac{\text { experimental release }- \text { spontaneous release }}{\text { total release }- \text { spontaneous release }} \times 100 \text {, }
$$

where spontaneous release represents counts released from control wells containing only $1 \times 10^{4}$ target cells, and total release represents counts obtained from an aliquot of $1 \times 10^{4}$ target cells. Cytotoxicity was also expressed as lytic units (LU)/ $10^{7}$ effector cells, defined as the number of effector cells needed to yield $30 \%$ cytotoxicity of $1 \times 10^{4}$ target cells. LU were calculated from the cytotoxicity curve using four different $\mathrm{E}: \mathrm{T}$ cell ratios for each test by linear regression analysis as described by Kadish et al. (18).

\section{Assay for $A D C C$}

The ADCC activity of effector cells was determined as previously described (6, $16,17)$. Briefly, $50 \mu \mathrm{l}$ of varying concentrations of effector cells were added to 50 $\mu \mathrm{l}$ of complete medium containing ${ }^{51} \mathrm{Cr}$-labeled SB target cells and $100 \mu \mathrm{l}$ of a 2 $\times 10^{-4}$ dilution of rabbit anti-SB antisera previously found to yield maximum ADCC. Percentage cytotoxicity was calculated as described above for NK activity with the following exceptions. Spontaneous release represents counts released in 
control wells containing effector cells, labeled SB target cells, and media instead of anti-SB antibodies, and total release represents counts obtained in an aliquot of 1 $\times 10^{4}{ }^{51} \mathrm{Cr}$-labeled target cells.

\section{Lectin-Dependent Cell-Mediated Cytotoxicity (LDCC) Assay}

The LDCC assay was carried out in a manner similar to that of the NK assay except that NK-resistant SB cells were used as targets. Briefly, different numbers of target and effector cells were added to V-bottom microtitration plates and various concentrations of phytohemagglutinin-P [PHA, Difco, Detroit, Mich. (1, 2.5, and 5 $\mu \mathrm{g} / \mathrm{ml})$ ] were added to a final volume of $0.2 \mathrm{ml}$ and incubated for $4 \mathrm{hr}$ at $37^{\circ} \mathrm{C}$ in a humidified $5 \% \mathrm{CO}_{2}$ in air incubator. Percentage LDCC activity was calculated as described for NK activity and was compared with cytotoxicity observed with control cultures containing effector and target cells in the absence of PHA. Percentage cytotoxicity was calculated as

$$
\% \text { cytotoxicity }=\frac{\text { experimental Release }- \text { spontaneous Release }}{\text { total Release }- \text { spontaneous Release }} \times 100,
$$

where spontaneous release represents counts released from control wells containing $1 \times 10^{4}$ target cells plus lectin and total release represents counts obtained in an aliquot of $1 \times 10^{4}$ target cells. The cytotoxicity was expressed as lytic units (LU)/ $10^{7}$ effector cells as described for NK assay.

\section{Interferon (IFN)}

Recombinant IFN- $\alpha$ (specific activity, $\sim 1 \times 10^{8} \mathrm{U} / \mathrm{mg}$ protein) was a gift from the Schering Corporation, Bloomfield, New Jersey. IFN- $\alpha$ was diluted in RPMI 1640 and stored at $-70^{\circ} \mathrm{C}$ before use. The maximum NK-augmenting dose was $250 \mathrm{U} / \mathrm{ml}$ as previously determined. IFN- $\alpha$ was diluted in RPMI 1640 medium and stored at $-70^{\circ}$ before use.

\section{Interleukin $2(I L-2)$}

Commercially available IL-2 (Electro-Nucleonics Labs, Inc., Silver Spring, Md.) was diluted in RPMI 1640 and stored at $-70^{\circ} \mathrm{C}$ before use. IL-2 was purified from human peripheral blood leukocytes by several chromatographic steps and was devoid of any lectin or IFN. A $10 \%$ final concentration, the maximum NKaugmenting dose as previously determined, was used.

\section{Treatment of Effector Cells with IFN or IL-2}

Effector cells $\left(2 \times 10^{6} / \mathrm{ml}\right)$ were washed and suspended in $1 \mathrm{ml}$ of RPMI 1640 plus 5\% FCS to which IFN- $\alpha$ or IL-2 was added. Cultures were incubated for $24 \mathrm{hr}$ at $37^{\circ} \mathrm{C}$ in a humidified atmosphere of $5 \% \mathrm{CO}_{2}$ in air, washed twice, and resuspended in medium. Control cultures were treated identically with the exception that either IFN- $\alpha$ or IL-2 was not added. Viability of treated lymphocytes was unaffected as assessed by trypan blue dye exclusion. Both treated and control cultures were assayed for NK activity. 


\section{Target-Binding Assay}

A target-binding assay was used as described by Haliotis et al. (19). In brief, lymphocytes were washed twice and mixed with a fivefold excess of tumor cells, centrifuged at $150 \mathrm{~g}$ for $5 \mathrm{~min}$, and incubated at $37^{\circ} \mathrm{C}$ for $5 \mathrm{~min}$. Following incubation, lymphocyte-target mixtures were transferred to ice, the pellets were gently resuspended, and the number of lymphocytes binding to tumor targets was determined using a hemocytometer.

\section{Interferon Assay}

Lymphocytes were cultured alone or with K562 target cells at a ratio of 100:1 for $18 \mathrm{hr}$ at $37^{\circ} \mathrm{C}$ in $5 \% \mathrm{CO}_{2}$ in air, after which they were centrifuged and the supernates were collected for IFN assay. Supernates were quantitated for IFN using a modified colorimetric assay of Borden and Leonhardt (20). Briefly, 96-well flatbottom microtitration plates (CoStar) were seeded with the human epithelial cell line WISH at a concentration of $3 \times 10^{4}$ cells/well in $0.1 \mathrm{ml}$ of media and incubated for $18 \mathrm{hr}$. Serial dilutions of supernates $(1: 10,1: 40,1: 160$, and $1: 320)$ were added in $0.1 \mathrm{ml}$ and incubated again for $18 \mathrm{hr}$. The cells were then infected with vesicular stomatitis virus, 200 plaque forming units/well, for $24 \mathrm{hr}$. After development of cytopathic effect the cultures were washed with PBS and overlaid with $0.2 \mathrm{ml}$ of $0.015 \%$ neutral red in saline and incubated for $2 \mathrm{hr}$ at $37^{\circ} \mathrm{C}$. The monolayers were washed and the cell-bound dye was eluted with a 1:1 solution of absolute ethanol: $0.2 \mathrm{M} \mathrm{NaH} \mathrm{PO}_{4}$. As a control, an IFN preparation standardized against $\mathrm{NIH}$ reference G023-901-527 of known concentrations ranging from 2 to $300 \mathrm{U} / \mathrm{ml}$ was included in the assay. This assay is highly reproducible and can detect as little as 4 $\mathrm{U} / \mathrm{ml}$ of IFN.

\section{Generation of Soluble Natural Killer Cytotoxic Factor (NKCF)}

The preparation of NKCF was carried out as described by Farram and Targan (21). Briefly, effector cells were mixed with NK-sensitive unlabeled K562 target cells at a 100:1 effector-to-target-cell ratio for $24 \mathrm{hr}$ in sterile $\mathrm{V}$-bottom microtitration plates (Dynatech Labs, Alexandria, Va.). They were then centrifuged at $150 \mathrm{~g}$ for 10 min, and the supernates (NKCF) were collected and tested for cytotoxic activity against fresh target cells. As controls, either K562 or effector cells were incubated separately in media alone and supernates were collected as described above and used as mock NKCF.

\section{Assay for NKCF}

K562 target cells were labeled with ${ }^{51} \mathrm{Cr}$ as described above and suspended at a concentration of $1 \times 10^{5}$ cells $/ \mathrm{ml}$ to which NKCF or mock NKCF at a final concentration of $25 \%(\mathrm{v} / \mathrm{v})$ was added and incubated for $24 \mathrm{hr}$ at $37^{\circ} \mathrm{C}$ in $5 \% \mathrm{CO}_{2}$ in air. At the end of incubation, the plates were centrifuged and $100-\mu 1$ aliquots were removed from each well and counted as described for the NK assay. Percentage cytotoxicity was calculated as

$\%$ cytotoxicity $=$

$$
\frac{\text { experimental release }(\mathrm{NKCF})-\text { spontaneous release }(\text { Mock NKCF) }}{\text { total release }- \text { spontaneous release }(\text { Mock NKCF) }} \times 100 \text {. }
$$




\section{RESULTS}

\section{NK and ADCC Activities of Cord Blood Lymphocytes}

Lymphocytes depleted of adherent cells from 15 cord blood and 10 adult peripheral blood samples were tested for their NK and ADCC activity against tumor target cells. Data presented in Table 1 show that CBL depleted of adherent cells demonstrated significantly lower NK and ADCC activities, respectively, against K562 and antibody-coated SB target cells compared to normal adult lymphocytes at all E:T cell ratios. E:T cell ratios higher than 50:1 produced similar differences (data not shown). The possibility that dilution of NK cells with other cells of the neonatal lymphocyte pool may be responsible for the diminution of NK and ADCC activities was examined using Percoll-enriched NK and ADCC effector cells. The data presented in Fig. 1 reveal that NK- and ADCC-enriched CBL from fraction "O" also showed significantly diminished NK $(25 \%, P<0.025)$ and ADCC $(21 \%$, $P<0.01)$ activities compared to higher NK $(68 \%)$ and ADCC (52\%) activities displayed by a similar Percoll fraction of a-PBL. CBL from fraction II also manifested lower levels of NK $(8 \%, P<0.05)$ and ADCC activities $(12 \%, P<0.025)$ as contrasted with the levels of NK $(26 \%)$ and ADCC $(18 \%)$ activities manifested by the same fraction of a-PBL. Lymphocytes from nonlytic fractions II to $\mathrm{V}$ of both CBL and a-PBL did not manifest significant differences in NK or ADCC activities.

\section{Target-Binding Ability of CBL}

To examine whether the diminished cytotoxicity observed with CBL is due to failure to interact with a target recognition structure rather than inhibition of the lytic mechanism, target-binding assays were performed. The results presented in

TABLE 1

NK and ADCC Activities of Cord and Adult Peripheral Blood Lymphocytes ${ }^{\star}$

\begin{tabular}{|c|c|c|c|c|c|}
\hline \multirow[b]{2}{*}{ Targets } & \multirow{2}{*}{$\begin{array}{l}\text { Effector } \\
\text { source }\end{array}$} & \multicolumn{4}{|c|}{$\begin{array}{l}\text { Effector:target cell ratio } \\
\text { Cytotoxicity }(\%)^{b}\end{array}$} \\
\hline & & $50: 1$ & $25: 1$ & $10: 1$ & $5: 1$ \\
\hline \multirow[t]{2}{*}{$\mathrm{K} 562^{c}$} & $\mathrm{a}-\mathrm{PBL}^{e}$ & $\begin{array}{c}51.2 \pm 15.6 \\
(P<0.025)^{g}\end{array}$ & $\begin{array}{c}37.7 \pm 10.0 \\
(P<0.01)\end{array}$ & $\begin{array}{c}19.6 \pm 5.0 \\
(P<0.025)\end{array}$ & $\begin{array}{c}12.6 \pm 2.3 \\
(P<0.005)\end{array}$ \\
\hline & $\mathrm{CBL}^{f}$ & $13.1 \pm 6.1$ & $9.2 \pm 4.6$ & $6.2 \pm 3.3$ & $3.6 \pm 2.1$ \\
\hline \multirow[t]{2}{*}{$\mathrm{SB}^{d}$} & a-PBL & $\begin{array}{l}39.5 \pm 9.5 \\
(P<0.05)\end{array}$ & $\begin{array}{c}29.4 \pm 8.2 \\
(P<0.05)\end{array}$ & $\begin{array}{c}23.6 \pm 5.6 \\
(P<0.025)\end{array}$ & $\begin{array}{c}8.5 \pm 1.9 \\
(P<0.025)\end{array}$ \\
\hline & CBL & $12.4 \pm 9.6$ & $10.5 \pm 6.3$ & $7.7 \pm 3.2$ & $2.6 \pm 1.7$ \\
\hline
\end{tabular}

\footnotetext{
${ }^{a}$ Effector cells were mixed with targets at varying $\mathrm{E}$ : $\mathrm{T}$ cell ratios in a $4-\mathrm{hr}{ }^{51} \mathrm{Cr}$ release assay. The results are means \pm SD of 15 different cord blood lymphocyte samples and 10 unrelated adult peripheral blood lymphocyte samples.

${ }^{b}$ Percentage cytotoxicity was calculated as under Materials and Methods.

c Erythroleukemia cell line used as targets in the NK assay.

${ }^{a}$ B-Leukemia cell line sensitized with anti-SB antibody used as targets in the ADCC assay.

' Adult peripheral blood lymphocytes depleted of adherent cells.

${ }^{f}$ Cord blood lymphocytes depleted of adherent cells.

${ }^{g}$ Differences in values between CBL and a-PBL were statistically significant at all E:T ratios in both NK and ADCC assays using a single-tailed Student's $t$ test.
} 


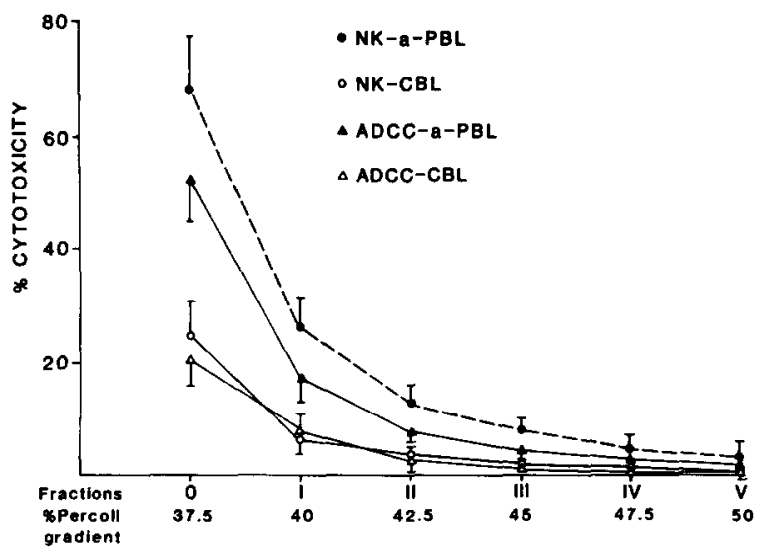

FIG. 1. NK and ADCC activities of Percoll-enriched cord blood lymphocytes and adult peripheral blood lymphocytes. Values represent mean percentage cytotoxicity \pm SD of three separate experiments with triplicate determinations for each experiment at 20:1 E:T cell ratio. Statistical significance was determined using a single-tailed Student's $t$ test.

Table 2 show that CBL demonstrated a lower percentage of conjugates formed with target cells $(6.5 \%)$ compared to a-PBL $(13.5, P<0.05)$. This suggests that the NK deficiency of CBL may be associated with defects in binding events.

\section{Effect of Lectin on Cellular Cytotoxicity of CBL}

Since CBL demonstrated reduced NK and ADCC activities and target binding ability compared to a-PBL, we examined whether the cytotoxic activity of CBL could be stimulated with lectin. Data presented in Table 3 demonstrate that a-PBL produced significantly increased cytotoxicity, i.e., $19(P<0.05), 22(P<0.05)$, and $18(P<0.025) \mathrm{LU}$ against SB targets at $1,2.5$, and $5 \mu \mathrm{g} / \mathrm{ml}$ of PHA, respectively, compared to a negligible cytotoxicity ( $5 \mathrm{LU}$ ) displayed in the absence of PHA. CBL exhibited a cytotoxicity of 4 LU without PHA which was significantly enhanced to $31(P<0.05), 31(P<0.05)$, and $49(P<0.05)$ LU by PHA at $1,2.5$, and $5 \mu \mathrm{g} /$

TABLE 2

Target Binding Ability of Cord Blood Lymphocytes ${ }^{a}$

\begin{tabular}{|c|c|}
\hline Effector cells & Target-binding lymphocytes $(\%)^{b}$ \\
\hline $\mathrm{a}-\mathrm{PBL}^{c}$ & $\begin{array}{c}13.5 \pm 3.1 \\
(P<0.05)^{e}\end{array}$ \\
\hline $\mathrm{CBL}^{d}$ & $6.5 \pm 2.4$ \\
\hline
\end{tabular}

\footnotetext{
a Effector and target cells were mixed at an E:T ratio of $5: 1$ and incubated at $37^{\circ} \mathrm{C}$ for $30 \mathrm{~min}$, followed by $0^{\circ} \mathrm{C}$ for $1 \mathrm{hr}$. Aliquots were examined in a hemocytometer and $\%$ positive target-binding cells was scored for each lymphocyte binding two or more target cells. Results are expressed as means \pm SD of 15 CBL and 7 a-PBL samples performed in duplicate.

${ }^{b}$ The human erythroleukemia cell line, K562, was used as target in the binding study.

' Adult peripheral blood lymphocytes depleted of adherent cells.

${ }^{a}$ Cord blood lymphocytes depleted of adherent cells.

' Statistical significance was determined using a single-tailed Student's $t$ test.
} 
$\mathrm{ml}$ concentrations, respectively. These data demonstrate that the percentage enhancement of cytotoxicity by PHA was greater for CBL than for a-PBL.

\section{Ability of $C B L$ to Produce Soluble NKCF}

We further investigated whether a decreased ability of CBL to synthesize and release NKCF might be responsible for their diminished cytotoxicity when compared to a-PBL. Data presented in Table 4 show that culture supernates (NKCF) of CBL plus target cells manifested decreased cytotoxicity (14\%) against fresh K562 target cells as compared to a higher cytotoxicity (24\%) displayed by NKCF produced by a-PBL $(P<0.05)$. This suggests that diminished production and secretion of NKCF may, in part, explain the decreased cytotoxicity of CBL.

\section{Effect of IFN- $\alpha$ and $I L-2$ on the NK Activity of $C B L$}

IFN- $\alpha$ and IL-2, agents known to augment the NK activity of lymphocytes, were examined for their potential to enhance the decreased cytotoxicity of CBL (Table 5). We observed that a-PBL precultured with IFN- $\alpha$ for $24 \mathrm{hr}$ produced higher cytotoxicity (137 LU) compared to a lower cytotoxicity (86 LU) displayed by untreated lymphocytes $(P<0.05)$. Preculture of a-PBL with IL-2 also demonstrated a significantly higher cytotoxicity of $173 \mathrm{LU}$ compared to $86 \mathrm{LU}$ shown by untreated a-PBL $(P<0.01)$. CBL precultured with IFN and IL-2 also showed an enhancement of their cytotoxicity, $122 \mathrm{LU}(P<0.05)$ and $183 \mathrm{LU}(P<0.005)$, respectively, compared to $58 \mathrm{LU}$ produced by untreated CBL. These data indicate that although the cytotoxicity of CBL could not be enhanced to absolute values comparable to a-PBL levels, the percentage enhancement of cytotoxicity of CBL by IFN- $\alpha(110.6 \%)$ and IL-2 (215\%) was remarkably higher than a-PBL augmented by IFN (59\%) and IL-2 (110\%).

\section{TABLE 3}

Effect of Lectin on Cellular Cytotoxicity of Lymphocytes ${ }^{a}$

\begin{tabular}{lccccc}
\hline & \multicolumn{5}{c}{ Cytotoxicity $(\mathrm{LU})^{b}$} \\
\cline { 2 - 6 } $\begin{array}{c}\text { Lymphocyte } \\
\text { source }\end{array}$ & $\begin{array}{c}\text { PHA } \\
\text { concentrations } \\
(\mu \mathrm{g} / \mathrm{ml}) ;\end{array}$ & 0 & 1 & 2.5 & 5 \\
\hline a-PBL & & $5.4 \pm 2.9$ & $19.8 \pm 5.7[266]^{e}$ & $22.8 \pm 6.4[322]$ & $18.7 \pm 4.6[246]$ \\
& & & $(P<0.05)^{f}$ & $(P<0.025)$ & $(P<0.025)$ \\
CBL $^{d}$ & $4.6 \pm 3.2$ & $31.2 \pm 11.7[578]$ & $31.3 \pm 11.0[580]$ & $49.7 \pm 18.5[980]$ \\
& & & $(P<0.05)$ & $(P<0.05)$ & $(P<0.05)$ \\
\hline
\end{tabular}

${ }^{a}$ The LDCC assay was carried out in a manner similar to that of the NK assay except the NK-resistant SB cell line was used as targets as described under Materials and Methods.

${ }^{b}$ Cytotoxicity is expressed as LU $/ 10^{7}$ effector cells as described under Materials and Methods. Values are mean $L U \pm S D$ of four separate experiments performed in triplicate.

${ }^{c}$ Adult peripheral blood lymphocytes depleted of adherent cells.

${ }^{d}$ Cord blood lymphocytes depleted of adherent cells.

${ }^{e}$ Values in brackets are $\%$ enhancement of LDCC calculatcd in comparison to control.

${ }^{f}$ Statistical values were determined by a single-tailed Student's $t$ test. 
TABLE 4

Effect of Soluble Natural Killer Cytotoxic Factor from Cord and Adult Peripheral Blood Lymphocytes on K562 Targets ${ }^{a}$

\begin{tabular}{cc}
\hline Source of NKCF & Cytotoxicity $^{b}(\%)$ \\
\hline a-PBL $+\mathrm{K} 562^{c}$ & $24.2 \pm 4.7$ \\
& $(P<0.05)^{e}$ \\
$\mathrm{CBL}+\mathrm{K} 562^{d}$ & $13.8 \pm 1.9$ \\
\hline
\end{tabular}

a Adult PBL or CBL were precultured separately with NK-sensitive unlabeled $\mathrm{K} 562$ target cells at an E:T cell ratio of $100: 1$, for $24 \mathrm{hr}$ at $37^{\circ} \mathrm{C}$ in $5 \% \mathrm{CO}_{2}$ in air. The supernates were collected and used as putative NKCF against fresh ${ }^{51} \mathrm{Cr}$-labeled $\mathrm{K} 562$ target cells at a final concentration of $25 \%(\mathrm{v} / \mathrm{v})$ as described under Materials and Methods. Results are the means of 10 different CBL-NKCF and 7 different a-PBL-NKCF samples \pm SD performed in triplicate.

${ }^{b}$ Calculated as under Materials and Methods.

${ }^{c}$ Adult peripheral blood lymphocytes depleted of adherent cells + unlabeled K562 target cells.

${ }^{d}$ Cord blood lymphocytes depleted of adherent cells + unlabeled K562 target cells.

' Differences in values between PBL and CBL were statistically significant using a single-tailed Student's $t$ test.

\section{Interferon- $\gamma$ Production by CBI, in Vitro}

Susceptibility of target cells to NK lysis may be partially dependent upon the ability of effector lymphocytes to produce IFN against the target cells (22). As CBL demonstrated diminished NK activity, target binding, and NKCF production compared to a-PBL, we examined whether the ability of CBL to produce IFN- $\gamma$ in vitro against $\mathrm{K} 562$ tumor targets could also be correlated with their reduced cytotoxic response. Data presented in Table 6 demonstrate that all CBL samples produced

TABLE 5

Effect of IFN and IL-2 on NK Activity of Lymphocytes ${ }^{a}$

\begin{tabular}{lcccc}
\hline Effector cells & Treatment & \multicolumn{2}{c}{ Cytotoxicity $(\mathrm{LU})^{b}$} & $\begin{array}{c}\text { Percentage } \\
\text { enhancement }^{c}\end{array}$ \\
\hline a-PBL & None & $86.2 \pm 12.2$ & & - \\
a-PBL & IFN & $137.2 \pm 22.4$ & $(P<0.05)^{f}$ & 59.1 \\
a-PBL & IL-2 & $173.0 \pm 23.9$ & $(P<0.01)$ & 100.6 \\
CBL $^{e}$ & None & $58.2 \pm 8.2$ & & - \\
CBL & IFN & $122.6 \pm 27.6$ & $(P<0.05)$ & 110.6 \\
CBL & IL-2 & $183.5 \pm 32.3$ & $(P<0.005)$ & 215.2 \\
\hline
\end{tabular}

${ }^{a}$ Effector cells were cultured alone or with IFN $(250 \mathrm{U} / \mathrm{ml})$ or IL-2 $(10 \% \mathrm{v} / \mathrm{v})$ for $24 \mathrm{hr}$ at $37^{\circ} \mathrm{C}$, washed, and tested for NK activity against prelabeled $\mathrm{K} 562 \mathrm{~b}$ target cells.

${ }^{b} \mathrm{NK}$ reactivity was calculated as LU/10 $0^{7}$ effector cells as under Materials and Methods. Values represent mean $\mathrm{LU} \pm \mathrm{SD}$ of five separate experiments done in triplicate.

${ }^{c}$ Percentage enhancement was calculated in comparison to the NK reactivity of untreated control lymphocytes.

${ }^{d}$ Adult peripheral blood lymphocytes depleted of adherent cells.

${ }^{e}$ Cord blood lymphocytes depleted of adherent cells.

${ }^{f}$ Statistical significance was determined using a single-tailed Student's $t$ test. 
remarkably lower levels of IFN- $\gamma$, with a range of 4 to $1680 \mathrm{U} / \mathrm{ml}$ (except for one sample, No. 5, which produced $3685 \mathrm{U} / \mathrm{ml}$ ), in response to $\mathrm{K} 562$ target cells as compared to a higher level of IFN- $\gamma$ produced by a-PBL. Thus, reduced IFN- $\gamma$ production by CBL may also be associated, in part, with their decreased ability to mediate NK activity.

\section{DISCUSSION}

Since newborns are more susceptible to various infections than are adults $(1,2)$, analysis of their immune status is an important clinical parameter. Although deficiencies of both humoral and cell-mediated immunity have been observed in neonates, the underlying cellular and molecular mechanisms remain unclear. In humans, reports on the ontogeny of NK cells are conflicting (23-25). Defects in the ability of neonatal lymphocytes to mediate NK and ADCC activities against tumorand virus-infected targets have been described by several investigators $(9,11)$. Frazier et al. (26) showed that NK and ADCC activities of CBL against Herpes simplex virus (HSV)-infected Chang liver cells were lower than those of a-PBL. They further demonstrated that the NK and ADCC activities of lymphocytes from babies delivered by $\mathrm{C}$-section without labor were significantly lower than the NK and ADCC activities of lymphocytes from neonates delivered vaginally. The proportion of certain lymphocyte subpopulations like OKT $11^{+}(27), \mathrm{OKT}^{+}(28), \mathrm{HNK}^{+}(12$, 25 ), or $\mathrm{Fc}$ receptor ${ }^{+}(29)$ was also reported to be lower in newborns than adults. Numerous studies have shown the presence of active suppressor cells or their soluble mediators in CBL $(27,30)$. The present investigation (Table 1) shows that CBL from babies delivered vaginally demonstrate reduced $\mathrm{NK}$ and $\mathrm{ADCC}$ activities against tumor target cells compared to a-PBL.

NK and ADCC effector cells have been described as large granular lymphocytes (LGL) containing azurophilic granules with a high cytoplasmic:nuclear ratio and a sedimentation profile at lower densities in a Percoll gradient (31). Tarkkanen and Saksela (14) showed an equivalent percentage of LGL in neonates and adult mononuclear populations. Although the percentage yield of LGL in Percoll fractions 0 and $I$ are similar in both CBL and a-PBL populations (data not presented), the CBL subpopulation enriched on Percoll gradient fractions 0 and I demonstrated significantly lower NK and ADCC activities compared to an equal number of a-PBL similarly enriched (Fig. 1). CBL from fractions II to V (nonlytic fractions) showed negligible NK and ADCC activities, which suggested that CBL effector cells do not have sedimentation characteristics different from those observed with a-PBL. Further, we examined whether the diminished cytotoxicity of CBL may be due to a decreased target-binding ability of effector cells. It was observed that CBL exhibited a decreased target-binding capacity compared to a-PBL (Table 2), indicating that the reduced cytotoxicity of CBL may be partly due to a defective target-binding capacity in addition to a possible diminution of the intrinsic lytic mechanism of effector cells. This is consistent with the finding of Kohl et al. (32), who showed that total mononuclear cord blood cells manifest decreased early target cell recognition or binding against Chang liver target cells.

Several investigators have observed that NK cells function through the release of soluble mediator(s), namely natural killer cytotoxic factor. Exogenous NKCF has been demonstrated to be cytotoxic to sensitive target cells $(21,33)$. In the present 
report, we examined whether a decreased ability of CBL to synthesize and secrete NKCF is responsible for their reduced NK activity. Our results show that NKCF from CBL displayed significantly lower cytotoxicity compared to NKCF from a-PBL, suggesting that such a deficiency in NKCF production by CBL may be responsible, in part, for their decreased NK activity (Table 4).

IFN and IL-2 play a major role in immunoregulation $(6,34-38)$ and the augmentation of $\mathrm{NK}$ activity both in vitro and in vivo $(6,34,35)$. IFN appears to enhance NK activity by several mechanisms, including stimulation of noncytotoxic pre-NK cells to mature cytotoxic effector cells (24) or activation of mature NK cells that are transiently inactive $(36,37)$. Alternatively, IFN may potentiate endogenous lytic mechanisms by stimulating the development of new receptors or modulating preexisting effector cell surface molecules or their avidity $(24,36,38)$. It has also been shown that IL-2 can induce IFN; this has been used successfully in the establishment of NK clones (39). Recently Svedersky et al. (40) reported that augmentation of NK activity by IL- 2 and IFN involves overlapping mechanisms. The present investigation describes a higher relative response of CBL to IFN and IL-2 compared to a-PBL, although the cytotoxicity of the former was not enhanced to the same absolute levels shown by a-PBL. It is possible that a specific subpopulation of lymphocytes such as precursor effector or pre-NK cells, which may be more sensitive to IFN- $\alpha$ and IL-2 signals, may be more abundant in cord blood than in adult peripheral blood. Further, active cytotoxic effectors may be relatively decreased in cord blood compared to adult blood. Several investigators have demonstrated that spontaneous suppressor cell activity is greater in cord blood than in adult blood

TABLE 6

Interferon Activity of Culture Supernates from Effector and Target Cells ${ }^{a}$

\begin{tabular}{lr}
\hline Source of culture supernate & $\begin{array}{c}\text { Interferon activity } \\
(\mathrm{U} / \mathrm{ml})^{b}\end{array}$ \\
K562 + CBL-1 & 1680 \\
K562 + CBL-2 & 700 \\
K562 + CBL-3 & 230 \\
K562 + CBL-4 & $<4$ \\
K562 + CBL-5 & 3685 \\
K562 + CBL-6 & 420 \\
K562 + CBL-8 & 40 \\
K562 + CBL-9 & 160 \\
K562 + CBL-10 & 240 \\
K552 + a-PBL & 60 \\
K562 + a-PBL & 2800 \\
K562 + a-PBL & 2677 \\
K562 + a-PBL & 2163 \\
K562 + a-PBL & 2334 \\
\hline
\end{tabular}

\footnotetext{
a Mixtures of effector and unlabeled K562 target cells were set up at 100:1 E:T cell ratio at $37^{\circ} \mathrm{C}$ for $24 \mathrm{hr}$ in $5 \% \mathrm{CO}_{2}$ in air. Supernates were obtained from cell cultures and assayed for IFN as described under Materials and Methods.

${ }^{b}$ Results are expressed as means \pm SD of triplicate determinations of 10 individual CBL and 5 different a-PBL samples.
} 
$(3,41)$, and cord blood cells are able to produce soluble suppressor factors which are capable of inhibiting various functions of adult lymphocytes (30). Enhancement of NK activity by IFN may also be due to the inhibition of suppressor cells or their soluble products. This is supported by our earlier investigation in which the suppressive cffect of soluble suppressor factors produced by normal lymphocyte cultures on NK activity could be completely reversed by IFN (6). Bryson et al. (42) showed that human CBL can produce IFN- $\alpha$ and IFN- $\beta$ but not IFN- $\gamma$ when stimulated with PHA. IFN has been shown to enhance the cytotoxicity of lymphocytes against tumor and virus-infected target cells. The magnitude of and sensitivity to IFN production in vivo may determine, in part, the neonate's ability to resist infection. The present investigation demonstrates that CBL produce considerably less IFN- $\gamma$ in vitro in response to tumor target cells in comparison with a-PBL. Although our functional assay does not discriminate the type of IFN present, treatment of culture supernates containing IFN at acidic $\mathrm{pH}(\mathrm{pH} 2-3)$ eliminated the IFN activity, demonstrating that IFN- $\gamma$ was produced by CBL in response to tumor target cells (Table 6). This deficiency of IFN- $\gamma$ production may be due to a dysfunction of accessory cells (43) or to the effect of suppressor cells or their mediators $(30,44)$.

Since the fetus represents an allograft in the maternal environment, a decrease in the cytotoxic response of the feto-maternal unit may inhibit graft-vs-host reactions as well as facilitate the expansion and development of hematopoietic stem cells which are known to be regulated by NK cells (8). In view of the significant ability of IFN or IL-2 to enhance the NK activity of neonatal lymphocytes as reported herein, these important biological modifier agents may have therapeutic potential in the treatment of severe neonatal viral infections.

\section{ACKNOWLEDGMENTS}

The authors express their sincere appreciation to Denise DuPrie for her expert secretarial help and to Katherine Albertson, Lynette McCurry, and Jean Cilik for their excellent technical assistance.

\section{REFERENCES}

1. Janeway, C. A., Arch. Dis. Child. 41, 358, 1966.

2. Schaffer, A. J., and Avery, M. E., "Diseases of the Newborn," p. 633. Saunders, Philadelphia, 1971.

3. Dwyer, J. M., and Johnson, C., Cell. Immunol. 81, 81, 1983.

4. Herberman, R. B. (Ed.), In "NK Cells and Other Natural Effector Cells" Academic Press, New York, 1984.

5. Nair, M. P. N., Fernandes, A., Onoe, K., Day, N. K., and Good, R. A., Int. J. Cancer 25, 667, 1980.

6. Nair, M. P. N., and Schwartz, S. A., J. Immunol. 129, $2511,1982$.

7. Nair, M. P. N., and Schwartz, S. A., Cell. Immunol. 81, 45, 1982.

8. Cudkowicz, G., and Hochman, P. S., Immunol. Rev. 44, 13, 1979.

9. Kohl, S., Frazier, J. P., Pickering, L. K., and Loo, L. S., J. Pediatr. 98, 783, 1981.

10. Antovelli, P., Stewart II, W., and Dupont, B., Clin. Immunol. Immunopathol. 19, 161, 1981.

11. Kaplan, J., Shope, T. C., Bollinger, R. O., and Smith, J., J. Clin. Immunol. 2, 350, 1982.

12. Hashimoto, G., Wright, P. F., and Karzon, D. T., Infect. Immun. 42, 214, 1983.

13. Uksila, J., Lassila, O., and Hirvonen, T., Clin. Exp. Immunol. 48, 649, 1982.

14. Tarkkanen, J., and Saksela, E., Scand. J. Immunol. 15, 149, 1982.

15. Boyum, A., Scand. J. Clin. Lab. Invest. 21, Suppl. 97, 77, 1968.

16. Nair, M. P. N., and Schwartz, S. A., J. Immunol. 126, 2221, 1981.

17. Nair, M. P. N., and Schwartz, S. A., J. Immunol. 132, 2876, 1984.

18. Kadish, A. S., Doyle, A. T., Steinhauer, E. M., and Ghossein, N. A., J. Immunol. 127, 1817, 1981. 
19. Haliotis, T., Roder, J., Klein, M., Ortaldo, J., Fauci, A. S., and Herberman, R. B., J. Exp. Med. 151, $1039,1980$.

20. Borden, E. C., and Leonhardt, P. H., J. Lab. Clin. Med. 89, 1036, 1977.

21. Farram, E., and Targan, S. R., J. Immunol. 130, 1252, 1983.

22. Santoli, D., Trinchieri, G., and Kaprowski, H., J. Immunol. 121, 532, 1978.

23. Rosenberg, E. B., Herberman, R. B., Levine, P. H., Halterman, R. H., McCoy, J. L., and Wunderlich, J. R., Int. J. Cancer 9, 648, 1972.

24. Saksela, E., Timonen, T., and Cantell, K., Scand. J. Immunol. 10, 257, 1979.

25. Abo, T., Cooper, M. D., and Balch, C. M., J. Exp. Med. 155, 321, 1982.

26. Frazier, J. P., Kohl, S., Pickering, L. K., and Loo, L. S., Pediatr. Res. 16, 558, 1982.

27. Rodriguez, M. A., Bankhurst, A. D., Ceuppens, J. L., and Williams, R. C., Jr., J. Clin. Invest. 68, $1577,1981$.

28. Maccario, R., Nespoli, L., Mingrab, G., Vitiello, A., Ugazio, A. G., and Burgio, G. R., J. Immunol. 130, $1129,1984$.

29. Witemeyer, S., Bankhurst, A. D., and Williams, R. C., Jr., Cell. Immunol. 30, 54, 1977.

30. Olding, L. B., Murgita, R. A., and Wigzell, H., J. Immunol. 119, $1109,1977$.

31. Timonen, T., and Saksela, E., J. Immunol. Methods 36, 285, 1980.

32. Kohl, S., Loo, L. S., and Gonik, B., J. Infect. Dis. 150, 14, 1984.

33. Wright, S. C., Weitzen, M. L., Kahle, R., Granger, G. A., and Bonavida, B., J. Immunol. 130, 2479, 1983.

34. Herberman, R. B., Ortaldo, J. R., and Bonnard, G. D., Nature (London) 277, 221 , 1979.

35. Lattime, E. C., Pecoraro, G. A., and Stutman, O., J. Exp. Med. 157, 1070, 1983.

36. Perussia, B., and Trinchieri, G., J. Immunol. 126, 754, 1981.

37. Bishop, G. A., and Schwartz, S. A., Clin. Immunol. Immunopathol. 25, 374, 1982.

38. Ortaldo, J. R., Pestka, S., Slease, R. B., Rubinstein, M. I., and Herberman, R. B., Scand. J. Immunol. 12, 365, 1980.

39. Pearlstein, K. T., Palladino, M. A., Welte, K., and Vilcek, J., Cell. Immunol. 80, 1, 1983.

40. Svedersky, L. P., Shepard, H. M., Spencer, S. A., Shalaby, M. R., and Palladino, M. A., J. Immunol. 133, 714, 1984.

41. Miyawaki, T., Seki, H., Kubo, M., and Taniguchi, N., J. Immunol. 123, 1092, 1979.

42. Bryson, Y. J., Winter, H. S., Gard, S. E., Fischer, T. J., and Stiehm, E. R., Cell. Immunol. 55, 191, 1980.

43. Epstein, L. B., Cline, M. J., and Merigan, T. C., J. Clin. Invest. 50, 744, 1971.

44. Hayward, A. R., and Lawton, A. R., J. Immunol. 119, 1213, 1977. 